International

\title{
YOUTH POLICY INNOVATION IN THE NETHERLANDS: THE REALIZATION OF CENTERS FOR YOUTH AND FAMILIES BY MUNICIPALITIES
}

\author{
WOUTER JANS, ARIANA NEED, MINNA VAN GERVEN, AND \\ BAS DENTERS \\ UNIVERSITY OF TWENTE
}

\begin{abstract}
In many countries "one-stop shops" have been considered an innovative mode of integrated service delivery in case of cross-cutting problems in fields such as sustainability, social exclusion, and youth policy. In this article, we explore how the Dutch national government implemented the innovative "one-stop shop" concept in municipal youth policies (Center for Youth and Family; CYF). In particular, we examine the conditions affecting the timing of the realization of these centers in Dutch municipalities between 2008 and 2012. We found considerable differences among municipalities in the timing of the realization of CYFs. In explaining these differences, we assumed motivations to be more important than obstacles and resources, because municipalities received financial compensation, and because CYFs can be considered a social policy innovation. Our findings indicate that the degree of political alignment between the municipal council and national government is an important motivation, and that increasing numbers of adopting municipalities in the same policy network and organizational capacity were important resources. Thus, opposite to what theory suggested, we found that resources were more important than motivations for the realization of CYFs. These findings challenge the decentralization thesis.
\end{abstract}

\section{BACKGROUND AND RESEARCH QUESTIONS}

Beginning in the 1990s, various European countries have implemented local government reforms aimed at establishing joined-up or holistic governance in the light of so-called cross-cutting issues (Christensen, Fimreite, and Lægreid 2007; Stewart et al. 1999; Considine 2002; Perri 6 et al. 2002; Pollitt 2003; Van Gerven 2008). Such cross-cutting issues require collaboration across organizational boundaries of government agencies and possibly cooperation with non-governmental organizations (Stewart et al. 1999). 
Dealing with typically interrelated, multi-faceted problems, youth problems offer a textbook case of such a cross-cutting issue. Coping with youth problems requires concerted action by a multitude of agents and agencies in fields like education, health care, child protection, police, housing, and various social services. In an effort to deal with youth problems as a cross-cutting issue, the Dutch national government in 2007 decided to decentralize many responsibilities for youth care to the municipalities. The main assumption underlying this decentralization was that a transfer of responsibilities in this domain would facilitate an integrated approach to youth problems at the street level in the different municipalities. This transfer of responsibilities, however, was by no means unconditional. It was accompanied by the requirement that all Dutch municipalities should establish a local Center for Youth and Family (CYF; J\&G 2008). These centers were intended to be "one-stop shops," providing joined-up services for the local young. Similar centers are also found in countries like Finland, Belgium, Germany, and the UK, with initiatives quite similar to the CYFs in the Netherlands (Dijk et al. 2008; Van Gerven 2008). In the UK, for example, local governments were made responsible for the implementation of so-called Children Centres, which are integrated facilities designed for parents and unborn children and children to about five years old (Vink 2007). Moreover, such "one-stop shops" are also used in other domains of (local) service delivery as a tool for better integration of services to citizens (see Pollitt 2003:44; Pollitt and Bouckaert 2004:85).

By the end of 2011, all municipalities were expected to have established such a center, resulting in a nationwide network of CYFs where all relevant local organizations in the field would collaboratively provide the necessary support to the young, their parents, and educators (J\&G 2007). The Netherlands is a decentralized unitary state (Pollitt and Bouckaert 2004) consisting of three tiers of government: the national government located in The Hague, 12 provinces, and 415 municipalities at the time of this study. Each tier of government is formed on the basis of independent democratic elections generally held once every four years. Dutch municipalities are relatively autonomous to the provinces and national government, as they are "free to define tasks and to use all their powers, as long as these do not conflict with national or provincial statutes" (Denters and Klok 2005:66). The national government played a major role in the realization of CYFs by imposing their implementation on municipalities. The provinces played a more modest role in that they were one of the organizations with which municipalities had to partner. For their finances, municipalities are for the most part depending on money from a municipal fund, from which money is distributed to the municipalities based on a rather complex formula in which the number of inhabitants is a major factor (Andeweg and Irwin 2009). To a lesser extent, municipalities depend on revenues from local taxes and general-purpose block grants. For municipalities, the realization of a CYF was a major policy innovation for which they needed additional funding, which they received via such a block grant from the national government.

Whereas most studies on innovations in local government have studied voluntary innovations (Rogers 2003), in this article we focus on a mandated policy innovation. This is important because innovations in local government are frequently adopted under the influence of national policy initiatives. To accelerate local policy innovations, national governments have used measures such as financial incentives (Berry and Berry 2007), standards or guidelines (Dahl and Hansen 2006; Walker, Avellaneda, and Berry 2011), 
and performance measurements (Julnes and Holzer 2001; Nutley et al. 2012). In the case of central government interventions, municipalities retain their autonomy in deciding to adopt or not to adopt a particular innovation. Sometimes, however, national governments move one step further and actually impose innovations on local governments (Zhu 2014; Jans et al. 2016). Such mandatory innovations are often introduced when - inspired by an egalitarian ethos-welfare states want to provide all citizens, irrespective of their place of residence, with equal rights and equal access to vital social services, such as child protection (Gabriel and Eisenmann 2005). In such cases, the national government not only tells municipalities what they can or should do, but also dictates (at least in part) how they should perform their new tasks. In this article, we study the actual adoption of a new mode of managing - the realization of CYFs - instead of only the adoption decision, as is common in innovation research (see Berry and Berry 2014). What we investigate is the result of an adoption and implementation process leading to the realization of a CYF. ${ }^{1}$ The findings of this article extend beyond its mere relevance for the CYF case, as the chosen case is quite typical for how decentralizations are carried out in the Netherlands (Van der Steen and Van Twist 2014) and elsewhere (Denters and Rose 2005).

The realization of CYFs in Dutch municipalities provides an ideal opportunity to investigate local governments' implementation of such a national mandate for the implementation of new policies. It has been argued that national mandates effectively bring an end to the process of diffusion of innovations, because they leave local governments no choice but to adopt a particular policy innovation (Karch 2006:406). Mandated policy innovations are therefore often believed to be a "highly uninteresting form of diffusion, as nearly all state discretion is eliminated by national-level fiat" (Berry and Berry 2007:231). Contrary to this conventional belief, we argue that mandated policy innovations are important cases to study. We cannot assume that municipalities act precisely as they are instructed to; generally, they may have more or less discretion in deciding on and implementing their mandatory tasks (Goldsmith 2005; Goldsmith and Page 2010). In this case, for example, municipalities were given a period of four years to implement the CYF in their jurisdiction, giving them the room for early or late implementation. Understanding the reasons why some municipalities are early implementers of mandated innovations and others are lagging behind may be interesting because the innovation adoption and implementation process is not simple and straightforward (Boyne et al. 2005). Studying the reasons for early and late implementation sheds light on factors determining this process.

Against this background, we investigate why some municipalities are relatively early or rather late in youth policy implementation than others, by answering two research questions: (1) What differences exist among Dutch municipalities in the timing of the realization of a CYF? (2) How can we explain differences in the timing of the realization of CYFs among Dutch municipalities?

\section{THEORY AND HYPOTHESES}

To explain variations in the timing of the realization of CYFs between municipalities, we will derive predictions from rational choice theory as postulated by Mohr (1969:114), who states that motivation and resources are positively related to innovation, and that 
obstacles are negatively related to innovation (see also Berry and Berry 2007). In the case of realizing CYFs in municipalities, this means that when the willingness to realize them is high, obstacles that can delay realization are small, and the available resources are large, the probability of municipalities realizing a CYF will be high. Rational choice explanations assume that when actors face problems, they will select solutions that are, given the circumstances, most in line with their preferences and desires (Hedström 2005:61). This is also applicable to our case; after all, municipalities are able to determine the moment of adoption.

Rational choice theory considers the motivations, resources, and obstacles of municipalities to consist of both internal and external factors (Berry and Berry 1990). Internal factors often refer to a government's political, economic, and societal conditions (Berry and Berry 2007). External mechanisms refer to the idea that governments learn from each other's policy experimentations. There is a substantial amount of evidence of governments learning from other governments (Shipan and Volden 2012). Allard (2004), for example, found that state decisions regarding Mothers' Aid programs were followed by similar decisions in neighboring states. Sugiyama (2008) showed that social programs diffuse across Brazil, due to public officials who adhere to policy-favorable professional norms because of socialization in professional networks. For mandated innovations, it is important to study the possible effects of external intergovernmental factors in addition to internal factors. It can be expected that when local governments are all charged with the same assignment, they will watch each other closely. Furthermore, in performing mandated tasks, local governments are generally closely monitored by the national government. It has been found, for example, that local governments whose political composition more closely resembled that of the national government were quickest to obey mandated tasks (Jans et al. 2016).

It has been repeatedly empirically identified that both motivations and resources play an important role when governments adopt innovations (Berry and Berry 2007). However, the impact of motivations, resources, and obstacles differs between policy areas (Gray 1973; Damanpour and Schneider 2009). For example, resources were found to be less important for the diffusion of moral policies than they were for administrative or technical innovations (Boushey 2010), and motivational factors were found to be more important in the adoption process of a social policy (Gray 1973). Because the realization of CYFs is of direct societal importance, and because municipalities received financial compensation for the realization of CYFs, we do expect motivations - both political and ideological - to be more important than both resources and obstacles. Our Motivation Hypothesis thus reads: motivational factors have stronger effects than resource and obstacle variables. In the next section, we derive concrete hypotheses from rational choice theory (Berry and Berry 2007) concerning Mohr's (1969) motivations, obstacles, and resources that might affect how quickly municipalities will realize CYFs.

\section{Motivation}

Municipal governments may adopt and implement innovations because they have a strong motivation to do so (Mohr 1969; Berry and Berry 2007). The motivation to come up with new policies may have different origins. The first reason is that, when there are 
severe local problems, local governments might feel the urge to come up with solutions to these existing problems (Sapat 2004; Karch 2006). Second, motivations can be ideology driven. Ideological preferences and ideological differences between politicians and political parties can make it difficult to arrive at a common solution for local problems (Daley and Garand 2005; Makse and Volden 2011). On the other hand, when ideological preferences of politicians are in favor of change regarding a certain policy, implementation becomes much more likely ( $\mathrm{McNeal}$ et al. 2003). Problem severity and ideology as motivations for innovation both refer to what is known in the literature as policyseeking motivations (for example, Robertson 1976; Budge and Laver 1986; Ware 1992). In addition to these two possible policy-seeking motivations, there might also be vote-seeking motivations, which come from the desire of politicians and political parties to attract votes in order to win elections (Robertson 1976; Budge and Laver 1986; Ware 1992). Our general hypothesis concerning municipalities' motivation to realize a CYF is that they will do this sooner when they feel strongly motivated. We derive one hypothesis concerning the need for the policy, we derive two hypotheses concerning ideological preferences, and we derive one hypothesis concerning vote-seeking motivations.

It has been argued that decisions to opt for specific policy solutions are dependent on the perceived severity of the problems (Berry and Berry 2007; Karch 2007a). The severity of a problem can be a motivation to innovate since it can clarify the need for the policy, or because societal groups demand adequate policy solutions (Berry and Berry 2007:235). Sapat (2004) found, for example, that state agencies were likely to adopt innovations to confront problems that were created by hazardous waste contamination. Karch (2006) hypothesized that the diffusion of individual development accounts (IDAs) increased with the (problematic) number of births to teenage mothers in a state. Thus, we assume that when municipalities face more problems against which the aims of the policy are targeted, they will try to mitigate these problems earlier than when they experience fewer problematic situations. Our Problem Severity Hypothesis is that municipalities will realize a CYF earlier when they experience more youth-related problems.

Next, we derive two hypotheses that reflect governments' ideology. First, it has often been argued that the political composition of governments influences the likelihood of innovation adoption (Berry and Berry 1990; Boehmke and Witmer 2004; Sugiyama 2008). When a new policy reflects the preferences of the main ideology in a municipality, it is more likely that it will be implemented. The Netherlands has a multi-party system based on proportional representation with most political parties that are active in national parliament also having local departments active in most municipalities. Municipal elections are, in essence, second-order national elections, with the only exception being the local political parties (which are not active in the national parliament) which have obtained over $20 \%$ of the votes since the local elections of 2006 (Andeweg and Irwin 2009). In the Netherlands, the Christian parties - the Christian Democrats (CDA), the Reformed Protestant Party (SGP), and the Christian Union (CU) - are traditionally associated with a strong preference for family policies. Our Government Ideology Hypothesis: Municipalities will realize a CYF earlier when they have a larger share of Christian parties in their council.

Second, it has been argued that vertical or top-down pressure is important in the innovation process because it can influence both the speed of the diffusion process 
(Berry and Berry 2007) and the substance of the innovation (Karch 2006). The willingness to obey a central mandate is derived from ideological differences between the national government and local governments (Jans et al. 2016). In a multi-party system where similar parties play a role in national politics and local politics, comparing governments' political composition vis-à-vis each other makes sense. Thus, our Political Alignment Hypothesis: Municipalities will realize a CYF earlier when their party preferences are more aligned with those of the national government.

Finally, a vote-seeking motivation that has often been hypothesized to affect governments' innovation decisions is electoral competition (McNeal et al. 2003). Local politicians who are facing closely contested elections are expected to embrace new programs to try to broaden their electorate (Berry and Berry 2007; García-Sánchez, Rodríguez-Domínguez, and Gallego-Álvarez 2011). We argue that municipalities with more party competition are more strongly motivated to come up with new policies. Our Electoral Competition Hypothesis: Municipalities will realize a CYF earlier when they have higher levels of party competition.

\section{Obstacles}

Mohr (1969) also considers obstacles to be of importance in the adoption and implementation of new polices (see Berry and Berry 2007). Our general hypothesis about the obstacles to innovate is that municipalities that face more obstacles will be later adopters than those having fewer obstacles. We derive one hypothesis from this general hypothesis.

An important obstacle to innovation is the disagreement between politicians or policymakers as to whether there is a problem for which governmental action is needed (Karch 2007a). This disagreement on what measures need to be taken is also assumed to be higher among more fragmented governments (Haider-Markel and Meier 1996; Allen 2005). For example, Brooks (2005) argued that the chances of winning majority support in the legislative process decline when political powers are shared broadly across distinct political parties. Thus, our Party Fragmentation Hypothesis: Municipalities will realize a CYF later when local political fragmentation is stronger.

\section{Resources}

In addition to motivations and obstacles, Mohr (1969) recognizes resources as a third factor that is important for innovation. A municipalities' command over financial, human, and social resources is argued to be important for the diffusion of innovations (Berry and Berry 2007). Financial resources refer to the amount of revenues a municipality receives, human resources refer to the quantity and quality of available staff, and social resources refer to a municipality's access to relevant networks. Our general hypothesis concerning the influence of resources is that municipalities with more resources will adopt the innovation sooner than municipalities with fewer resources, even if the municipalities were given money from the central government to realize CYFs. We derive four specific hypotheses from this general hypothesis. 
The first municipal resource is organizational capacity (Walker 1969; Ahn 2011). Organizations with more command over financial and human capital are generally more inclined to adopt innovations than less resourceful organizations are. Therefore, our Organizational Capacity Hypothesis: Municipalities will realize a CYF earlier when they have greater organizational capacity.

Second, political attention is considered an important resource, because policy priorities of governments determine, to a large extent, the amount of available resources for the implementation of new programs or policies (Jacoby and Schneider 2001). The priorities of governments can become visible by the decision to formalize these priorities via an area-specific political portfolio (Jans et al. 2016). Appointment of a "Youth" alderman was also one of the recommendations of the aforementioned advisory committee, known as Operation Young. We assume that if the main governing body of a municipality, which is the Board of the Mayor and Aldermen (hereafter referred to as BMA), has a mayor or aldermen with "Youth" in its portfolio, it will likely allocate more personal and financial resources for the CYF realization. Thus, our Youth Portfolio Hypothesis: Municipalities will realize a CYF earlier when their BMA has a youth-specific portfolio.

Third, it has been shown that governments do not make decisions in isolation. That is why horizontal networks are considered to be an important resource (DiMaggio and Powell 1991; Balla 2001; McNeal et al. 2003). Professional networks are important for politicians and policymakers to exchange information and to acquire relevant information (Balla 2001; McNeal et al. 2003; Sugiyama 2008). Networks create a setting where policymakers can discuss the latest developments, standards, and many municipal-level policy innovations. We expect municipalities with leadership in a professional network to be better informed of the latest developments, and thus more likely to conform to the latest developments. Our Professional Network Hypothesis: Municipalities will realize a CYF earlier when they have leadership in a professional network.

Fourth, other horizontal networks can be considered a resource. In the literature, an often-used proxy measure for intergovernmental contact leading to the spread of policies is geographic proximity. One of the first scholars to conclude that states adopted new programs more often when other similar states had already adopted them was Walker (1969). Support has been found for the claim that policies diffuse across neighboring governments (for example, Berry and Berry 1990; Volden 2006). However, it is not so clear why proximity should lead a policy to diffuse (Beck, Gleditsch, and Beardsley 2006; Karch 2007b). Therefore, we use a more direct conceptualization. To do so, we take into account the places where policymakers exchange or acquire their information (Füglister 2011). Our Policy Network Hypothesis: Municipalities will realize a CYF earlier when there are more municipalities in the same policy network that already have realized a CYF.

\section{DATA AND METHOD}

Information about the years in which municipalities realized a CYF was collected from the annual reports about the broad goal-oriented grants for the CYFs (Houwer et al. 20082011). The Minister of $Y \& F$ announced his plans in the policy program in September 
2007 (J\&G 2007), and in a letter to all municipalities in January 2008, it was explained what the specific role was for the municipalities in the CYF implementation (J\&G 2008). For all municipalities, the first possible year of realization was 2008; the last realization took place in 2012. The potential number of adopting municipalities was 415 in 2012. Because of missing values, we run our analysis on 381 municipalities $(91 \%)$. In terms of size, our sample is representative for the total population of Dutch municipalities. ${ }^{2}$

\section{Motivational Variables}

The variable PROBLEM SEVERITY is measured by a scale based on the Kinderen in Tel data book (Steketee, Mak, and Tierolf 2009), which is the Dutch equivalent of the American Kids Count. The scale we used included measures for child mortality, youth criminality, youth unemployment, youth care, children in disadvantaged neighborhoods, children in poverty, child abuse, children with learning disabilities and school absenteeism, and teenage mothers. We created a scale based on the average of the individual items. ${ }^{3}$

To measure GOVERNMENT IDEOLOGY, we estimate the percentage of politicians in the BMA from the Christian parties - the Christian Democrats (CDA), the Reformed Protestant Party (SGP), and the Christian Union (CU). The variable was constructed using data from the Dutch Association of Municipalities (VNG). ${ }^{4}$ This variable ranges between 0 and 100 .

To measure the similarity in political composition between the national government and local governments, we constructed the variable POLITICAL ALIGNMENT. This variable measures the proportion of political parties in a municipal council that are represented in the national government's coalition. The variable ranges between $0 \%$ and $100 \%$. An increase of the score on the variable indicates greater local-national party alignment. The variable is time varying and was constructed using data from local and national elections in 2006 and 2010..$^{5}$ Data were obtained from Kiesraad (2011).

The quantity of ELECTORAL COMPETION in a municipality is measured by the amount of electoral volatility between two election periods. The variable is calculated using the method proposed by Pedersen (1979). We calculated the volatility for two election periods. For 2008 and 2009, we calculated the volatility for the local elections of 2002 and 2006. For the years between 2010 and 2012, we calculated the electoral volatility for the elections of 2006 and 2010. A higher score means that a municipal council experiences more political competition. Data range between 1.67 and 71.43 , and are collected from the website nlverkiezingen.com (our own calculations). ${ }^{6}$

\section{Obstacle Variable}

We measure the amount of PARTY FRAGMENTATION in a municipality with the Laakso-Taagepera index (1979). This index reflects the effective number of political parties in a municipal council by taking into account their relative size. A higher score means a more fragmented municipal council. We constructed this time-varying variable by using data from the 2006 and 2010 local elections. This covers the full period between 
2008 and 2012. Data range between 0.16 and 10.07, and come from the Electoral Council (Kiesraad 2006-2010).

\section{Resources Variables}

The measurement of ORGANIZATIONAL CAPACITY is based on the standardized logtransformed scores of the fulltime-equivalent (fte) municipal staff per 1000 inhabitants (BZK 2007-2011), and the amount of money municipalities received from the municipal fund per 1000 inhabitants (BZK 2008-2011). We combined these two variables into one reliable scale for the years 2008 to 2012. For both variables, only the scores of 2008 are used, because the scores were highly comparable across all five years (municipal fund correlations $=1,000$ for all years; the fte correlations are all $>0.893$ ). A factor analysis and a subsequent reliability test indicated that one organizational capacity scale could be constructed $(\alpha=0.814$ and eigenvalue $=1.697)$. The variable ranges between -5.03 and 11.19.

We measure BMA PORTFOLIO with 0 if a municipality had no mayor or alderman who was responsible for the Youth portfolio or the Health Care and Municipal Health Service portfolio, and with 1 if it had a mayor or alderman with such responsibilities formalized in a portfolio. Data come from the Dutch Association of Municipalities (VNG). ${ }^{7}$

We measured leadership in a PROFESSIONAL NETWORK with a dummy variable taking the value of 0 if a municipality had no representation in the leadership of a provincial VNG department, and 1 if it had leadership. The boards of the provincial VNG department are usually composed of mayors and aldermen. Occasionally, local councilors also serve on the board. These provincial departments have the task of providing municipalities with information about issues that arise in the province, and they also represent the interests of the municipalities. Data are self-collected from the annual reports of the provincial departments.

To measure the POLICY NETWORK, we constructed a variable measuring the cumulative number of municipalities in a policy network that already adopted a CYF. Municipalities all have their own Municipal Health Services (in Dutch: Gemeentelijke Gezondheidsdienst, hereafter referred to as MHS), which are all accommodated in larger organizational networks, the so-called MHS-regions. The network classification is based on information from the National Institute for Public Health and the Environment (in Dutch: Rijksinstituut voor Volksgezondheid en Milieu (RIVM)) (RIVM 2008). This variable is time varying and ranges between $0 \%$ and $100 \%$.

Each municipality potentially contributes multiple records, one for each year, to our data set. Having repeated measures can lead to problems of temporal dependence. Therefore, we include $t$ (time), $t^{2}$ and $t^{3}$ (Carter and Signorino 2010). ${ }^{8}$ We have found multicollinearity to be a problem, and therefore demeaned $t$, and used $t / 100$, and its square. For reasons of interpretation, we standardized (z-scores) all interval variables. Table 1 presents the means, standard deviations, and range of the original scales of all variables used in our analyses.

We test our hypotheses by using Event History Analysis (EHA), which estimates the probability that a municipality will realize a CYF in a specific year, given that it has not already done so in previous years (Berry and Berry 1990; Singer and Willett 2003). We constructed a municipality-year dataset containing a record for each 
TABLE 1

Descriptive Statistics $(N=1147, N$ Clusters 381$)$

\begin{tabular}{llrrrc}
\hline & Time Varying & Mean & sd & Min. & Max. \\
\hline $\begin{array}{l}\text { Dependent variable } \\
\text { CJG ADOPTION }\end{array}$ & yes & 0.33 & 0.47 & 0 & 1 \\
Motivational variables & & & & & \\
PROBLEM SEVERITY & no & -0.05 & 0.56 & -1.36 & 2.76 \\
GOVERNMENT IDEOLOGY & yes & 30.54 & 20.73 & 0 & 100 \\
POLITICAL ALIGNMENT & yes & 58.38 & 23.34 & 0 & 100 \\
ELECTORAL COMPETITION & yes & 18.91 & 10.11 & 1.67 & 71.43 \\
Obstacle variable & & & & & \\
PARTY FRAGMENTATION & yes & 5.06 & 1.21 & .16 & 10.07 \\
Resources variables & & & & & \\
ORGANIZATIONAL CAPACITY & no & -0.12 & 1.75 & -5.03 & 11.19 \\
YOUTH PORTFOLIO & yes & 0.75 & 0.44 & 0 & 1 \\
PROFESSIONAL NETWORK & yes & 0.29 & 0.45 & 0 & 1 \\
ADOPTION POLICY NETWORK & yes & 39.26 & 32.22 & 0 & 100 \\
Duration & & & & & \\
YEARS & yes & 2.18 & 1.03 & 1 & 5 \\
\hline
\end{tabular}

municipality for each year it is "at risk" of adoption. For each municipality, the dependent variable is coded zero, except for the year in which it adopts a CYF. For the year of adoption, the dependent variable takes on the value of one, and consequently there are no further records for municipalities for the years after they had realized a CYF. The risk set therefore decreases in size over time. Parameters of our models are estimated by using standard logistic regression analysis.

\section{ANALYSES AND RESULTS}

In this section, we answer our two research questions. We will now answer the first question: What differences exist among Dutch municipalities in the timing of the realization of a CYF? Table 2 shows the major events and timelines that were discussed in the introduction, and that are crucial in the process of CYF realization by municipalities. The cumulative distribution of adoptions demonstrates that it took over two years for the adoption rate to increase firmly. The increase in adoptions was strongest in the years 2010 and 2011. This is not very surprising when we consider that the central government ministry set the deadline by the end of the year 2011. In 2012, there was only one municipality realizing a CYF. By that time, all municipalities in the Netherlands had realized a CYF. Of all municipalities, in $200813 \%$ had a CYF, in $200926 \%$, in $201062 \%$, in $201199 \%$, and in $2012100 \%$. On the basis of Table 2, we conclude with regard to our first question that there was considerable variation among municipalities in the timing of CYF adoptions. The cumulative distribution of CYF adoption over time shows that the pattern of CYF adoptions indeed resembles, to some extent, the well-known s-curve from the literature (Rogers 2003). This suggests that it is indeed possible to examine theories 
TABLE 2

Major Events and Timelines of the Adoption of CYFs

\begin{tabular}{|c|c|c|c|c|c|}
\hline \multirow[b]{2}{*}{ Event } & \multirow[b]{2}{*}{ Timeline } & \multirow[b]{2}{*}{ Year } & \multirow{2}{*}{$\begin{array}{c}\mathrm{N} \\
\text { mun. }\end{array}$} & \multicolumn{2}{|c|}{ CYF Adoption } \\
\hline & & & & $\%$ of mun. & $\%$ change \\
\hline National elections & 22 November 2006 & 0 & - & - & - \\
\hline $\begin{array}{l}\text { Inauguration cabinet } \\
\text { Balkenende IV (2006- } \\
\text { 2010) and } \\
\text { announcement of new } \\
\text { Ministry for Youth and } \\
\text { Family }\end{array}$ & 22 February 2007 & 0 & - & - & - \\
\hline $\begin{array}{l}\text { Policy program Ministry } \\
\text { for Youth and Family }\end{array}$ & September 2007 & 0 & - & - & - \\
\hline $\begin{array}{l}\text { Letter from Ministry for } \\
\text { Youth and Family to } \\
\text { municipalities presented } \\
\text { to the parliament }\end{array}$ & 16 November 2007 & 0 & - & - & - \\
\hline Letter from Ministry for & January 2008 & 0 & - & - & - \\
\hline Youth and Family to & December 2008 & 1 & 53 & 13.0 & 0 \\
\hline municipalities & December 2009 & 2 & 53 & 26.0 & 13.0 \\
\hline National elections & 9 June 2010 & - & - & - & - \\
\hline Inauguration cabinet Rutte & October 2010 & - & - & - & - \\
\hline I (2010-2012) and & December 2010 & 3 & 146 & 61.9 & 35.9 \\
\hline abolishment of Ministry & December 2011 & 4 & 154 & 99.8 & 37.8 \\
\hline for Youth and Family & December 2012 & 5 & 1 & 100.0 & 0.2 \\
\hline
\end{tabular}

that were developed for voluntary governance innovations to understand mandated innovations. These findings imply that when the national government sets a mandate, this does not mean that local governments will instantly react, or that they will all react at the same time, or that all local governments will meet the deadlines set. It is clear that municipalities used discretion when it comes to the time frame of realization. The shown differences in the timing of realization make clear that studying these types of innovations is substantially more interesting than previously suggested (e.g., Karch 2006; Berry and Berry 2007). Of course, vertical pressures by the national government played an important role in the implementation of CYFs, as we have seen from the strong increase in adoptions in 2010 and 2011 when the deadline approached. Thus, in understanding processes of innovations, there is also clearly a need to understand processes of mandated innovations.

Now we will answer our second research question: How can we explain differences in the timing of the realization of CYFs among Dutch municipalities? Our dependent variable is a dichotomous measure of whether a municipality realizes a CYF in a particular year, and therefore we employ logistic regression analysis. Parameters are estimated using Stata/IC 13.1. In Table 3, we present the estimated coefficients, robust standard errors, and the Akaike Information Criterion (AIC) value as measurement for the model fit. Regression 


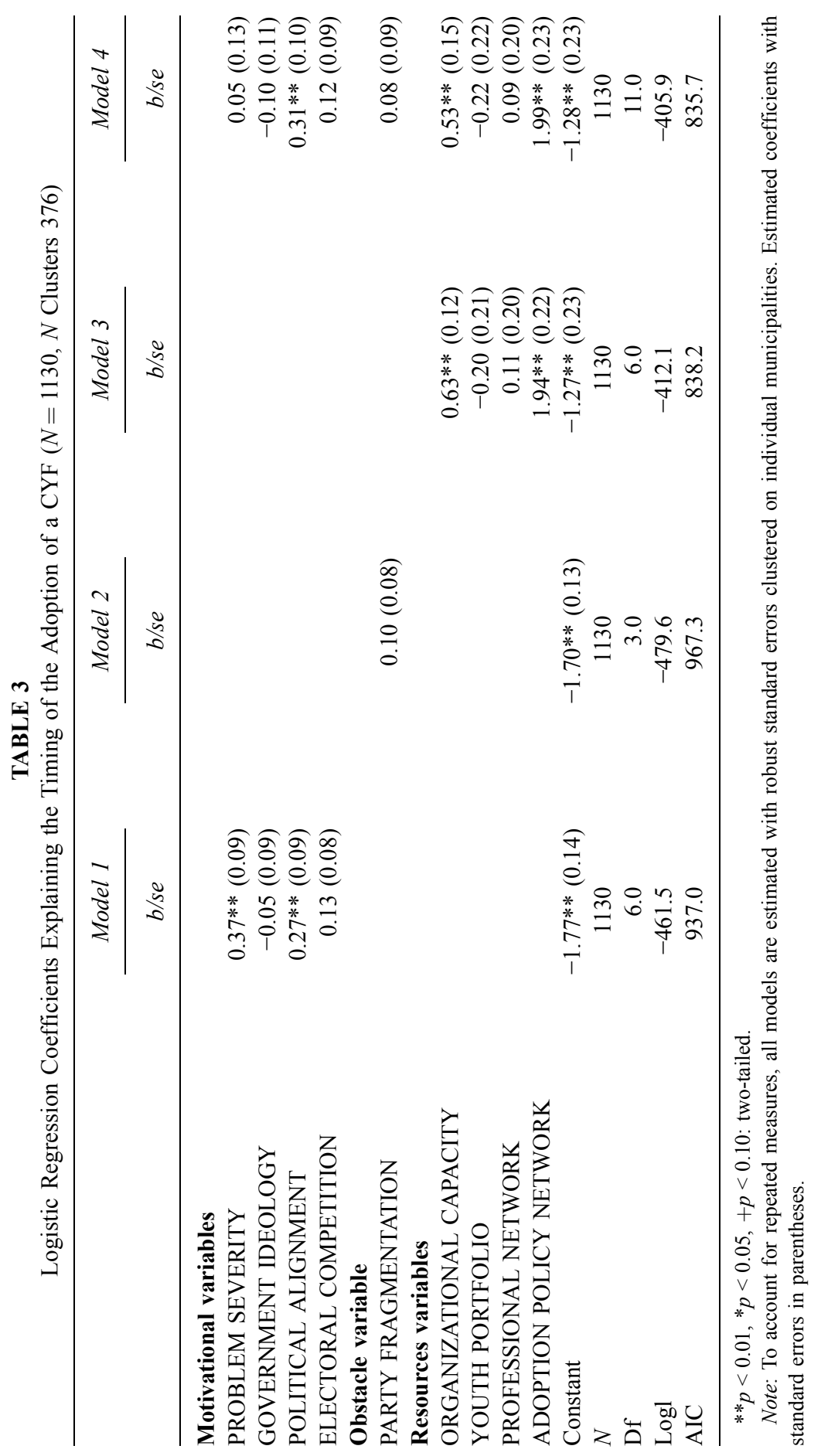


diagnostics were performed and revealed only minor problems that had dealings with influential cases. We removed five influential municipalities from our analyses. ${ }^{9}$

In Model 1, we examine the association between CYF realization and the motivational factors, in Model 2 we do this for the obstacles, and in Model 3 we test for the influence of resources. Model 4 tests for the influence of all motivation, obstacles, and resources variables. In a final analytical step, we compare the effect sizes of the latent constructs motivations, obstacles, and resources to determine which was the most important for the timing of the realization of CYFs. To compare the relative effects of motivational variables to those of obstacles and resources, we compared the effect sizes of the different blocks of variables by calculating the sheaf coefficient (Heise 1972), implemented by the sheafcoef-package in Stata 13.1 (Buis n.d., 2010).

Model 1 in Table 3 shows the estimates of the effects of the variables that capture a municipality's motivation to innovate. We expected that more strongly motivated municipalities would realize a CYF earlier. The coefficient of the problem severity variable shows up in the expected positive direction, and is statistically different from zero $(p=0.000)$. This indicates that, in each year, municipalities experiencing more youth-related problems have a greater likelihood of CYF realization. A one-unit (one sd) increase in problem severity is associated with an approximate $44 \%\left(100^{*}\left(\left(\mathrm{e}^{\wedge} 0.366\right)-1\right)=44.2 \%\right)$ increase in the odds of CYF realization. The coefficient of the political alignment variable is also positive, in the expected direction, and statistically different from zero $(p=0.003)$. This means that, in each year, municipalities that are politically more aligned with the national government have a greater likelihood of realizing a CYF. A one-unit (one sd) increase in political alignment is approximately associated with a $31 \%$ increase in the odds of CYF realization. This is a provisional confirmation of our problem severity hypothesis and our political alignment hypothesis. The coefficients of the government ideology variable and the electoral competition variable do not attain conventional levels of statistical significance, and appear to be unrelated to the realization of CYFs. The overall implication of these findings is that, in general, hypotheses regarding motivation were only partly confirmed.

Model 2 in Table 3 shows the result of the variable reflecting the obstacles to CYF realization. We assumed that municipalities with fewer obstacles would be earlier adopters of a CYF. The coefficient of the party fragmentation variable does not appear to be statistically different from zero. This means that the party fragmentation hypothesis is, for the moment, rejected.

Model 3 in Table 3 shows the coefficients for the factors reflecting resources for CYF realization. We hypothesized that municipalities that were more resourceful would be earlier realizers of a CYF. The organizational capacity variable $(p=0.000)$ shows that, in each year, municipalities that have a larger organizational capacity have a greater likelihood of CYF realization. A one-unit (one sd) increase in organizational performance is associated with a $69 \%$ increase in the odds of CYF realization. The coefficient of the policy network is also positive and statistically different from zero $(p=0.000)$. This implies that, in each year, municipalities that have more municipalities in the same policy network that have already realized a CYF are more likely to realize a CYF earlier themselves. The effect of the policy network variable is very large; each additional unit (one sd) increase in this variable is associated with a rise of $597 \%$ in the odds of CYF 
realization. This implies an initial confirmation of the organizational capacity hypothesis and of the policy network hypothesis. The youth portfolio and the professional network variables fail to attain the conventional levels of statistical significance and thus appear to be unrelated to the timing of the realization of CYFs. These findings also mean that the general resources hypothesis is only partially confirmed.

The results of Model 4, where we tested simultaneously for the effects of motivation, obstacles, and resources, did slightly change the outcomes and results that we described earlier. For the motivational variables, only the political alignment variable seems to be related to the timing of CYF realization $(p=0.002)$. A one-unit (one sd) increase in political alignment is associated with an approximate $36 \%$ increase in odds of CYF realization, instead of the $31 \%$ in Model 1 . We can now definitely confirm the political alignment hypothesis. The other three hypotheses-problem severity, government ideology, and electoral competition - are now definitely rejected. The general motivation hypothesis is hereby only marginally confirmed. Again, the obstacle variable failed to attain conventional levels of statistical significance. The party fragmentation hypothesis and the general obstacles hypothesis are now definitely rejected. For the resources variables, both the coefficients of the organizational variable $(p=0.001)$ and the policy network variable $(p=0.000)$ are again positive and statistically different from zero. Compared to the results in Model 3, the results of the resources variables did not change for the organizational capacity variable, but they did change slightly for the policy network variable. A one unit (one sd) increase is now associated with a $632 \%$ increase in odds of CYF realization, compared to $597 \%$ in Model 3. Therefore, the youth portfolio hypothesis and the professional network hypothesis are now definitely rejected. The organizational hypothesis and the policy network hypothesis are hereby confirmed and, in general, the hypotheses regarding resources were only partially confirmed.

To test the relative impact hypothesis, we compare the effect sizes of the latent constructs motivations, obstacles, and resources. In doing so, we can determine which factor was the most important for explaining differences in the timing of the realization of CYFs. We calculated the sheaf coefficient (Heise 1972) by using the sheafcoef-package in Stata 13.1 (Buis n.d., 2010). The coefficient of the motivational variables block is 0.319 $(p=0.001)$, that of the resources block is $2.022(\mathrm{p}=0.000)$, and that of the obstacles block is $0.076(p=0.411)$. This means that obstacles played no role, and that resources were considerably more important than motivations in the adoption process of CYFs. This means that we have to reject our motivation hypothesis.

\section{CONCLUSION AND DISCUSSION}

The decentralization of responsibilities to implement policies has increased over the last few decades in several countries around the world. In the Netherlands, often characterized as a decentralized unitary state (Denters and Rose 2005:11), municipalities increasingly function as an extension of national government via co-governance arrangements (Denters and Klok 2005), meaning that municipalities are held responsible for the implementation of policies and laws that are nationally determined. In the case of the CYFs, the municipalities were not only burdened with a new task (here the development 
and implementation of an integrated youth policy), but also were legally obliged to do this in a particular manner. All municipalities were asked to set up a new local CYF. These centers aimed for an innovation of local youth policies by introducing the notion of a "one-stop shop" to secure better-integrated services for youth and their parents. In this article, we have investigated the dynamics of the implementation of this mandated innovation of local youth policy in Dutch municipalities. So far, the study of innovations has concentrated on voluntary innovations by municipalities, and has either neglected mandated innovations or considered these as uninteresting (e.g., Berry and Berry 2007:231). This, however, ignores the fact that, even in cases of mandated innovations, municipalities may have at least some discretion; for example, in the speed of implementing the centrally imposed policy innovations. In this article, we answered two questions: (1) What differences exist among Dutch municipalities in the timing of the realization of a CYF? (2) How can we explain differences in the timing of the realization of CYFs among Dutch municipalities?

We found differences in the speed of adoptions of CYFs. More than a quarter of all municipalities realized a CYF in 2009, and more than $60 \%$ of all municipalities realized a CYF in 2010, which was a year before the deadline set by the national government. This is a different picture than was shown, for example, with the adoption of a mandated administrative e-government innovation, where the deadline had to be postponed due to a significant lack of municipal compliance (Jans et al. 2016). Despite the overall rather timely realization of CYFs, we found differences in timing between municipalities which needed explanation.

To investigate the determinants for variations in timing between municipalities, we applied a model emphasizing the motivations, obstacles, and resources for innovation (Mohr 1969; Berry and Berry 2007). We found that when municipalities were politically more aligned to the national governments' coalition, they realized a CYF earlier. This indicates that municipalities are more responsive to policy initiatives that are initiated by their own political parties. Despite the fact that it is widely acknowledged that top-down pressures (Karch 2006; Berry and Berry 2007) and ideological preferences (McNeal et al. 2003) can be important in the innovation process, political alignment is a rather underexposed factor in innovation research (Jans et al. 2016). We also found that differences in organizational capacity were responsible for differences in the speed of adoptions. This is in line with other research (Walker 1969; Ahn 2011) but, in our case, it is quite striking that organizational capacity-which we measured by taking into account financial resources as well as human resources - still played such an important role in explaining differences in timing. Despite the financial compensation municipalities received via a national block grant, more resourceful municipalities still were quicker with realization of a CYF. A possible explanation for this might be that existing organizational structures are better developed in larger organizations, perhaps due to their past experiences or past performance in youth care (Jans et al. 2016), or because of the institutionalization of youth policies (Tolbert, Mossberger, and McNeal 2008). Future research into the adoption of social policies should try to take into account these types of measures for resources. The last significant finding was that policy networks played a role. When more municipalities in the same policy network adopted a CYF, the chances for municipalities' own adoption increased. This effect of intergovernmental contact as a driver for the spread of innovations 
has been found on numerous occasions (for example, Berry and Berry 1990; Volden 2006; Füglister 2011). We have also taken into account the influence of professional networks, but these were not significant predictors of adoption. Because policy networks were, this might indicate that youth policy is more strongly connected to administrative networks than to political networks.

In contrast with what was argued in other innovation studies (Haider-Markel and Meier 1996; Allen 2005; Brooks 2005), party fragmentation was not a significant obstacle for CYF realization. However, these were all studies investigating voluntary innovations. In another study of a mandated innovation, party fragmentation was also found to have no influence on the timing of adoption (Jans et al. 2016). Furthermore, although appointing an alderman who would be specifically responsible for youth policies was explicitly recommended by the National Advisory Committee for Youth Policy, having such an alderman did not have a significant impact on the speed of CYF implementation, indicating either a possible lack of institutionalization (Tolbert, Mossberger, and McNeal 2008) or a possible lack of policy entrepreneurship by the individual aldermen (Mintrom and Norman 2009). Future research should try to disentangle under what circumstances - that is, for different types of policies in either mandated or voluntary circumstances-policy entrepreneurs can be critical for the implementation of new policies.

To reinforce the theoretical arguments, we investigated the combined effects for the three Mohr (1969) factors. Although motivations, obstacles, and resources are often used to derive hypotheses about differences in innovativeness (for example, Berry and Berry 2007), as far as we know it is quite unique to compare the effects sizes for these three latent constructs (see Jans 2015). We found that obstacles were not important, and that resources were more important than motivations in the realization of CYFs. This latter result is opposite to what we initially expected, and to what was suggested in earlier research (Jans et al. 2016). We expected that motivations would be more important than resources because social policies presumably are politically more pertinent because they directly influence citizens' well-being, and are therefore close to the core interest of local politicians. Moreover, the central government provided municipalities with financial means to establish CYFs, thereby probably reducing the problem of insufficient financial capacity in setting up these centers. Nevertheless, we found that resources did still play a major role in setting up CYFs. This unexpected outcome is likely the result of a combination of factors. First, the limited importance of motivational factors may be the result of the mandated nature of this innovation: there was only limited scope for local discretion. Second, the degree of controversy on the CYF innovation may only have been limited. Third, we may have underestimated the importance of non-financial resources, knowledge and skills, and the capacity to network effectively with local partners in setting up the local CYF as things that money cannot (immediately) buy. Previous research on decentralization in the Netherlands has suggested that local governments are not always very well-equipped to deal with the challenges they face in the light of new tasks and responsibilities (Denters, van Heffen, and de Jong 1999). These challenges are probably even greater because establishing a CYF requires effective interorganizational cooperation and a "network answer." Although, in the end, people may agree that this "answer" is likely to improve the quality of service delivery, it might still hamper the speed of the implementation process (O’Toole 2015). 
The results in this article also have some interesting policy implications. The Dutch reform shows that it is possible to successfully implement a mandated major policy reform in the local public sector in a relatively short period of time. At least two factors are likely to have had a positive effect on this outcome. First of all, although the establishment of a CYF was centrally imposed on Dutch municipalities, this mandated innovation was combined with some degrees of freedom, both in terms of timing (municipalities were allowed considerable time to implement the reform locally) and in terms of substance (how and with whom to set up the center, etc.). It is likely that such a centrally prescribed "pill" may be easier to swallow for local governments than a rigid, detailed central government dictate. Second, the fact that the municipalities and their local partners were also provided with some extra funding (even though there were, of course, debates on the adequacy of funding) for this new local facility may also have contributed to the success. In addition to the positive lessons, our findings also suggest a point for concern. With the financial means, successful decentralizations also require that municipalities command nonfinancial resources. This relates to adequate knowledge of local circumstances and the skills to gear policies to meet local challenges. Moreover, in the age of local governance, effective decentralizations also require that municipalities are able to develop "network answers" (O'Toole 2015). Of course, this is primarily a local responsibility, but national governments and national unions of municipalities (and other intermunicipal bodies) can help in providing municipalities with the necessary human resources.

\section{NOTES}

1. When we talk about implementation, we refer to the adoption and implementation process leading to a new mode of managing (the realization of CYFs) and we do not focus on whether or not the implementation or roll-out of that new mode of managing was successful.

2. To check for representativeness in terms of size, we used a classification used by Statistics Netherlands: $<5,000 ; 5,000-10,000 ; 10,000-20,000 ; 20,000-50,000 ; 50,000-100,000 ; 100,000$ 150,$000 ; 150,000-250,000 ;>250,000$.

3. A confirmatory factor analysis (CFA) with the principal component (PA) extraction method, which was forced to look for one dimension, made us decide to remove the items "public playgrounds" and "infant mortality." We constructed a scale from the 10 remaining items. The eigenvalue was above 3.9 , and the communalities of the 10 single items were all above 0.30 except for two (which were 0.225 for infant mortality and 0.286 for school absenteeism), but these two items are substantively important and are therefore included in our scale. The test for the internal reliability of our scale resulted in a Cronbach's alpha $(\alpha)$ of 0.806 , which is good.

4. For the years 2008-2009, we used information from September 2006, and for the years 2010-2012 we used information from August 2010. In both cases, these data cover the composition of the BMA after local elections, which were respectively in March 2006 and March 2010.

5. National elections were held in November 2006 and June 2010. Local elections were held in March 2006 and March 2010. From 2008 (year 1) to 2010 (year 3), we compare the results of the local elections in 2006 with the results of the national elections in 2006. From 2011 (year 4) to 2012 (year 5), we compare results from the local elections in 2010 with the results of the national elections in 2010.

6. The information on the local elections of March 2002, March 2006, and March 2010 were retrieved from the website of Freek Ogink (nlverkiezingen.com; visited on June 26, 2013). The main 
source of information for election results for both national and local elections in the Netherlands is the website of the Electoral Council (kiesraad.nl). However, these election results consider local political parties as one broad category, which makes it computationally impossible to calculate the correct differences for all political parties in a municipality between two election periods.

7. See note 2 .

8. The table in Appendix 1 shows a comparison of alternative specifications for time (based on calculations proposed by Singer and Willett (2003:407-467)), on which basis we conclude that the model with the quadratic polynomial for time functions best, as it performs almost as well as the model with time dummies (general), but it needs fewer degrees of freedom. The quadratic specification for time outperforms the constant and linear specifications for time, and the cubic polynomial has no benefits over the quadratic specification. The figure in Appendix 1 shows us that the quadratic polynomial of time is quite capable of recovering the baseline hazard.

9. The five Wadden Island municipalities-Texel, Vlieland, Terschelling, Ameland, and Schiermonnikoog - were removed from our analyses. They proportionately have a lot of money and manpower for the maintenance of the island.

\section{REFERENCES}

Ahn, M. J. 2011. "Adoption of Applications in U.S. Municipalities: The Role of Political Environment, Bureaucratic Structure, and the Nature of Applications." The American Review of Public Administration 41(4):428-52. doi:10.1177/0275074010377654.

Allard, S. W. 2004. "Competitive Pressures and the Emergence of Mothers' Aid Programs in the United States." Policy Studies Journal 32(4):521-44. doi:10.1111/j.1541-0072.2004.00079.x.

Allen, M. D. 2005. "Laying Down the Law? Interest Group Influence on State Adoption of Animal Cruelty Felony Laws.” Policy Studies Journal 33(3):443-57. doi:10.1111/j.1541-0072.2005. 00124.x.

Andeweg, R. B. and G. A. Irwin. 2009. Governance and Politics of the Netherlands, 3rd ed. New York, NY: Palgrave Macmillan.

Balla, S. J. 2001. "Interstate Professional Associations and the Diffusion of Policy Innovations." American Politics Research 29(3):221-45. doi:10.1177/1532673x01293001.

Beck, N., K. S. Gleditsch, and K. Beardsley. 2006. "Space is More than Geography: Using Spatial Econometrics in the Study of Political Economy." International Studies Quarterly 50(1):27-44. doi:10.1111/j.1468-2478.2006.00391.x.

Berry, F. S. and W. D. Berry. 1990. "State Lottery Adoptions as Policy Innovations: An Event History Analysis." American Political Science Review 84(2):395-15. doi:10.2307/1963526.

Berry, F. S. and W. D. Berry. 2007. "Innovation and Diffusion Models in Policy Research." Pp. 223-60 in Theories of the Policy Process, 2nd ed., edited by P. A. Sabatier. Boulder, CO: Westview Press.

Berry, F. S. and W. D. Berry. 2014. "Innovation and Diffusion Models in Policy Research." Pp. 307-59 in Theories of the Policy Process, 3rd ed., edited by P. A. Sabatier and C. M. Weible. Boulder, CO: Westview Press.

Boehmke, F. J. and R. Witmer. 2004. "Disentangling Diffusion: The Effects of Social Learning and Economic Competition on State Policy Innovation and Expansion." Political Research Quarterly 57(1):39-51. doi:10.1177/106591290405700104.

Boushey, G. 2010. Policy Diffusion Dynamics in America. New York, NY: Cambridge University Press.

Boyne, G. A., J. S. Gould-Williams, J. Law, and R. M. Walker. 2005. "Explaining the Adoption of Innovation: An Empirical Analysis of Public Management Reform." Environment and Planning C: Government \& Policy 23(3):419-35. doi:10.1068/c40m. 
Brooks, S. M. 2005. "Interdependent and Domestic Foundations of Policy Change: The Diffusion of Pension Privatization around the World." International Studies Quarterly 49(2):273-94. doi:10.1111/j.0020-8833.2005.00345.x.

Budge, I. and M. Laver. 1986. "Office Seeking and Policy Pursuit in Coalition Theory." Legislative Studies Quarterly 11:485-506.

Buis, M. L. 2010. SHEAFCOEF: Stata Module to Compute Sheaf Coefficients. Statistical Software Components. (https://EconPapers.repec.org/RePEc:boc:bocode:s456995).

Buis, M. L. n.d. Combining Information from Multiple Variables using Models for Causal Indicators. Working Paper. Tübingen, Germany.

BZK. 2008-2011. "Distribution of Payments from the Municipal Fund [in Dutch: Verdeling van de uitkeringen uit het gemeentefonds] [data file]." Retrieved August 21, 2012 (http://www. rijksoverheid.nl/onderwerpen/gemeenten/documenten-en-publicaties/rapporten/2011/07/28/ verdeling-van-de-uitkeringen-uit-het-gemeentefonds.html).

BZK. 2007-2011. "Municipalities' Budget Analyses [in Dutch: Begrotingsanalyse gemeenten] [data file]." Retrieved April 15, 2012 (http://www.rijksoverheid.nl/documenten-en-publicaties/rapporten/).

Carter, D. B. and C. S. Signorino. 2010. "Back to the Future: Modeling Time Dependence in Binary Data." Political Analysis 18(3):271-92. doi:10.1093/pan/mpq013.

Christensen, T., A. L. Fimreite, and P. Lægreid. 2007. "Reform of the Employment and Welfare Administrations - The Challenges of Co-Coordinating Diverse Public Organizations." International Review of Administrative Sciences 73(3):389-408. doi:10.1177/0020852307081149.

Considine, M. 2002. "The End of the Line? Accountable Governance in the Age of Networks, Partnerships, and Joined-Up Services." Governance 15(1):21-40. doi:10.1111/1468-0491.00178.

Dahl, P. S. and K. M. Hansen. 2006. "Diffusion of Standards: The Importance of Size, Region and External Pressures in Diffusion Processes.” Public Administration 84(2):441-59. doi:10.1111/ j.1467-9299.2006.00011.x.

Daley, D. M. and J. C. Garand. 2005. "Horizontal Diffusion, Vertical Diffusion, and Internal Pressure in State Environmental Policymaking, 1989-1998." American Politics Research 33(5):615-44. doi:10.1177/1532673x04273416.

Damanpour, F. and M. Schneider. 2009. "Characteristics of Innovation and Innovation Adoption in Public Organizations: Assessing the Role of Managers." Journal of Public Administration Research and Theory 19(3):495-22. doi:10.1093/jopart/mun021.

Denters, B. and L. E. Rose. 2005. Comparing Local Governance: Trends and Developments. New York, NY: Palgrave Macmillan.

Denters, B. and P.-J. Klok. 2005. "The Netherlands in Search of Responsiveness." Pp. 65-82 in Comparing Local Governance: Trends and Developments, edited by B. Denters and L. E. Rose. New York, NY: Palgrave Macmillan.

Denters, B., O. van Heffen, and H. M. De Jong. 1999. "Proeftuin of Procrustesbed? Gemeentelijk Jeugd- en Veiligheidsbeleid in het Kader van het Grote-Stedenbeleid, 1995-1997." [Testbed or Procrustean-bed? Municipal Youth and Security Policy within the framework of the Major Cities Policy] Bestuurskunde 3:106-15.

Dijk, M., A. Kalsbeek, B. Prinsen, and P. Nota. 2008. "De Lessen Uit Vier Europese Landen." [The Lessons from Four European Countries] Jeugd En Co Kennis 4(2):39-47. doi:10.1007/bf03085942.

DiMaggio, P. J. and W. W. Powell. 1991. "The Iron Cage Revisited: Institutional Isomorphism and Collective Rationality in Organizational Fields." Pp. 63-82 in The New Institutionalism in Organizational Analysis, edited by W. W. Powell and P. J. DiMaggio. Chicago, IL: The University of Chicago Press.

Füglister, K. 2011. "Where Does Learning Take Place? The Role of Intergovernmental Cooperation in Policy Diffusion." European Journal of Political Research 51(3):316-49. doi:10.1111/ j.1475-6765.2011.02000.x. 
Gabriel, O. W. and S. Eisenmann. 2005. “Germany: A New Type of Local Government.” Pp. 119-38 in Comparing Local Governance: Trends and Developments, edited by B. Denters and L. E. Rose. New York, NY: Palgrave Macmillan.

García-Sánchez, I.-M., L. Rodríguez-Domínguez, and I. Gallego-Álvarez. 2011. “The Relationship between Political Factors and the Development of E-Participatory Government." The Information Society 27(4):233-51. doi:10.1080/01972243.2011.583816.

Goldsmith, M. 2005. “A New Intergovernmentalism?" Pp. 228-45 in Comparing Local Governance: Trends and Developments, edited by B. Denters and L. E. Rose. New York, NY: Palgrave Macmillan.

Goldsmith, M. and E. C. Page. 2010. Changing Government Relations in Europe: From Localism to Intergovernmentalism. London, England: Routledge.

Gray, V. 1973. "Innovation in the States: A Diffusion Study." The American Political Science Review 67(4):1174-85. doi:10.2307/1956539.

Haider-Markel, D. P. and J. Meier. 1996. "The Politics of Gay and Lesbian Rights: Expanding the Scope of the Conflict." The Journal of Politics 58(2):332-49. doi:10.2307/2960229.

Hedström, P. 2005. Dissecting the Social: On the Principles of Analytical Sociology. Cambridge, England: Cambridge University Press.

Heise, D. R. 1972. "Employing Nominal Variables, Induced Variables, and Block Variables in Path Analyses." Sociological Methods \& Research 1(2):147-73. doi:10.1177/004912417200 100201.

Houwer, J., M. De Jong, A. Richt, and V. Atalay. 2008-2011. Annual Report: Broad Goal-Oriented Grant Centers for Youth and Family [in Dutch: Jaarrapportage Brede Doeluitkering Centra voor Jeugd en Gezin]. Den Haag, Netherlands: BMC Onderzoek.

J\&G. 2007. All Opportunities for All Children, Youth and Family Program 2007-2011 [in Dutch: Alle Kansen voor alle Kinderen, Programma voor Jeugd en Gezin 2007-2011]. The Hague, Netherlands: Programmaministerie voor Jeugd en Gezin.

J\&G. 2008. Centers for Youth and Families and the Municipal Directive Role [in Dutch: Centra voor Jeugd en Gezin en Regierol Gemeente]. The Hague, Netherlands: Programmaministerie voor Jeugd en Gezin.

Jacoby, W. G. and S. K. Schneider. 2001. "Variability in State Policy Priorities: An Empirical Analysis." Journal of Politics 63(2):544-68. doi:10.1111/0022-3816.00078.

Jans, W. 2015. "Policy Innovation in Dutch Municipalities." Dissertation. University of Twente, Enschede, The Netherlands. doi:10.3990/1.9789036539876.

Jans, W., B. Denters, A. Need, and M. van Gerven. 2016. "Mandatory Innovation in a Decentralised System: The Adoption of an e-Government Innovation in Dutch Municipalities." Acta Politica 51(1):36-60. doi:10.1057/ap.2014.36.

Julnes, P. de L., and M. Holzer. 2001. "Promoting the Utilization of Performance Measures in Public Organizations: An Empirical Study of Factors Affecting Adoption and Implementation." Public Administration Review 61(6):693-708. doi:10.1111/0033-3352.00140.

Karch, A. 2006. "National Intervention and the Diffusion of Policy Innovations." American Politics Research 34(4):403-26. doi:10.1177/1532673x06288202.

Karch, A. 2007a. Democratic Laboratories: Policy Diffusion among the American states. Ann Arbor, MI: The University of Michigan Press.

Karch, A. 2007b. "Emerging Issues and Future Directions in State Policy Diffusion Research." State Politics \& Policy Quarterly 7(1):54-80. doi:10.1177/153244000700700104.

Kiesraad. 2006-2010. "Election Results. [in Dutch: Verkiezingsuitslagen] [data file]." Retrieved November 23, 2011. (http://www.verkiezingsuitslagen.n1/Na1918/Verkiezingsuitslagen.aspx/).

Laakso, M. and R. Taagepera. 1979. "The 'Effective' Number of Parties: A Measure with Application to West Europe.” Comparative Political Studies 12(1):3. doi:10.1177/001041407901200101. 
Makse, T. and C. Volden. 2011. "The Role of Policy Attributes in the Diffusion of Innovations." The Journal of Politics 73(1):108-24. doi:10.1017/S0022381610000903.

McNeal, R. S., C. J. Tolbert, K. Mossberger, and L. J. Dotterweich. 2003. "Innovating in Digital Government in the American States." Social Science Quarterly 84(1):52-70. doi:10.1111/ 1540-6237.00140.

Mintrom, M. and P. Norman. 2009. "Policy Entrepreneurship and Policy Change." Policy Studies Journal 37(4):649-67. doi:10.1111/j.1541-0072.2009.00329.x.

Mohr, L. B. 1969. "Determinants of Innovation in Organizations." The American Political Science Review 63(1):111-26. doi:10.2307/1954288.

Nutley, S., J. Downe, S. Martin, and C. Grace. 2012. "Policy Transfer and Convergence within the UK: The Case of Local Government Performance Improvement Regimes." Policy \& Politics 40(2):193-209. doi:10.1332/147084411x581880.

O'Toole, L. J. 2015. "Networks and Networking: The Public Administrative Agendas." Public Administration Review 75(3):361-71.

Pedersen, M. N. 1979. "The Dynamics of European Party Systems: Changing Patterns of Electoral Volatility.” European Journal of Political Research 7(1):1-26. doi:10.1111/j.1475-6765.1979. tb01267.x.

Perri 6, D., Leat, K. Setzler and G. Stoker. 2002. Towards Holistic Governance: The New Reform Agenda. Hampshire, England: Palgrave.

Pollitt, C. 2003. "Joined-up Government: A Survey." Political Studies Review 1(1):34-49. doi:10.1111/1478-9299.00004.

Pollitt, C. and G. Bouckaert. 2004. Public Management Reform: A Comparative Analysis, 2nd ed. New York, NY: Oxford University Press.

RIVM. 2008. “GGD-Regio's 2008: Nationale Atlas Volksgezondheid.” Retrieved December 18, 2014 (http:// www.zorgatlas.nl/thema-s/gebiedsindelingen-en-topografie/gebiedsindelingen/ggd-regio-s-2008/).

Robertson, D. B. 1976. A Theory of Party Competition. London, England: John Wiley \& Sons.

Rogers, E. M. 2003. Diffusion of Innovations, 5th ed. New York, NY: Free Press.

Sapat, A. 2004. "Devolution and Innovation: The Adoption of State Environmental Policy Innovations by Administrative Agencies." Public Administration Review 64(2):141-51. doi:10.1111/j.1540-6210.2004.00356.x.

Shipan, C. R. and C. Volden. 2012. "Policy Diffusion: Seven Lessons for Scholars and Practitioners." Public Administration Review 72(6):788-96. doi:10.111/j.1540-6210.2012.02610.x.Policy.

Singer, J. D. and J. B. Willett. 2003. Applied Longitudinal Data Analysis. New York, NY: Oxford University Press.

Steketee, M., J. Mak, and B. Tierolf. 2009. Kids Count Data Book 2009: Children Rights as the Basis for Local Youth Policy. [in Dutch: Kinderen in Tel databoek 2009: Kinderrechten als Basis voor Lokaal Jeugdbeleid.]. Utrecht, Netherlands: Verwey-Jonker Instituut.

Stewart, M., S. Goss, G. Gillanders, R. Clarke, J. Rowe, and H. Shaftoe. 1999. Cross-Cutting Issues Affecting Local Government. London, England: Department of the Environment, Transport and the Regions.

Sugiyama, N. B. 2008. "Theories of Policy Diffusion: Social Sector Reform in Brazil." Comparative Political Studies 41(2):193-16. doi:10.1177/0010414007300916.

Tolbert, C. J., K. Mossberger, and R. S. McNeal. 2008. "Institutions, Policy Innovation, and e-Government in the American States." Public Administration Review 68(3):549-63. doi:10.1111/j.1540-6210.2008.00890.x.

Van der Steen, M. and M. Van Twist. 2014. "Weerbaar of Wendbaar Zijn? Strategische Opties in de Voorbereiding op de drie Decentralisaties." [Being Resilient or Agile? Strategic Options in the Preparation for the three Decentralizations] Beleid En Maatschappij 41:1. doi:10.5553/benm/ 138900692014041001010. 
Van Gerven, M. 2008. "The Broad Tracks of Path Dependent Benefit Reforms: A Longitudinal Study of Social Benefit Reforms in Three European Countries, 1980-2006." Helsinki, Finland: The Social Insurance Institution.

Vink, C. 2007. "Engelse Inspiratie voor Nederlands Jeugdbeleid." [English Inspiration for Dutch Youth policy] Jeugd En Co Kennis 1(4):124-28. doi:10.1007/bf03085472.

Volden, C. 2006. "States as Policy Laboratories: Emulating Success in the Children's Health Insurance Program." American Journal of Political Science 50(2):294-12. doi:10.1111/j.15405907.2006.00185.x.

Walker, J. L. 1969. "Diffusion of Innovations among American States." American Political Science Review 63(3):880-99.

Walker, R. M., C. N. Avellaneda, and F. S. Berry. 2011. "Exploring the Diffusion of Innovation among High and Low Innovative Localities.” Public Management Review 13(1):95-25. doi:10.1080/14719037.2010.501616.

Ware, A. 1992. "Activist-Leader Relations and the Structure of Political Parties: 'Exchange' Models and Vote-Seeking Behaviour in Parties." British Journal of Political Science 22 (1):71-92. doi:10.1017/s0007123400000351.

Zhu, X. 2014. "Mandate Versus Championship: Vertical Government Intervention and Diffusion of Innovation in Public Services in Authoritarian China." Public Management Review 16(1):117-39. doi:10.1080/14719037.2013.798028.

\section{ABOUT THE AUTHORS}

Wouter Jans (wouterjans@live.nl) obtained his Ph.D. from the University of Twente in the Netherlands in the Department of Public Administration. His research focused on the adoption and diffusion of innovations in local government. He currently is a senior researcher at policy research company Dimensus in Breda, the Netherlands.

Ariana Need (a.need@utwente.nl) obtained her Ph.D. from the Radboud University Nijmegen, the Netherlands, in 1997, where she lectured in sociology. In 2009, she was appointed as a full professor in sociology and public policy at Twente University. Her current research focuses on the comparative study of the development and diffusion of innovations in public policy systems.

Minna van Gerven (Minna.vanGerven@utwente.nl) is an assistant professor in the Department of Public Administration of University of Twente. Her research focuses on comparative public policy, policy learning and diffusion. Her research has been published in Social Policy \& Administration, Policy \& Politics, and Journal of European Public Policy.

Bas Denters (s.a.h.denters@utwente.nl) is a full professor of public governance in the Department of Public Administration of the University of Twente. He is scientific director of the Netherlands Institute for Government (NIG): the KNAW-accredited Dutch/Flemish Graduate School for Political Science and Public Administration. Bas Denters has published on issues of urban governance, citizen involvement, and local democracy. 


\section{APPENDIX 1}

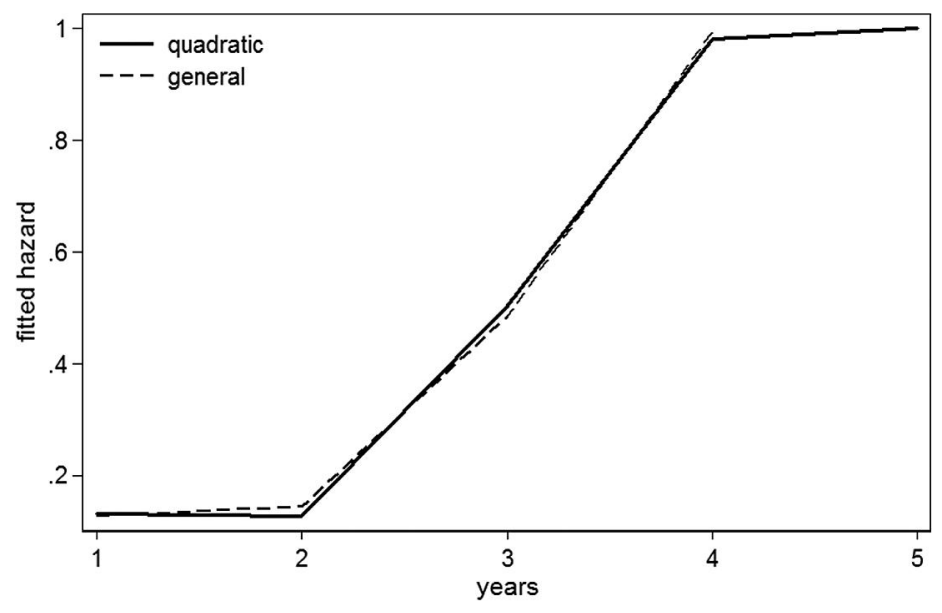

Figure A1. Fitted hazard function for the number of years until CYF adoption, with quadratic polynomial for the main effect of time (years).

TABLE A1

Justification for the Specification for the Control Variable Time

\begin{tabular}{|c|c|c|c|c|c|c|}
\hline \multirow[b]{2}{*}{$\begin{array}{l}\text { Representation } \\
\text { for Time }\end{array}$} & \multirow[b]{2}{*}{$\begin{array}{c}\mathrm{n} \\
\text { parameters }\end{array}$} & \multirow[b]{2}{*}{ Deviance } & \multicolumn{2}{|c|}{$\begin{array}{l}\text { Difference in Deviance } \\
\text { in Comparison to... }\end{array}$} & \multirow[b]{2}{*}{$A I C$} & \multirow[b]{2}{*}{$B I C$} \\
\hline & & & $\begin{array}{l}\text { Previous } \\
\text { Model }\end{array}$ & $\begin{array}{l}\text { General } \\
\text { Model }\end{array}$ & & \\
\hline Constant & 1 & 1458.31 & - & 488.30 & 1460.31 & 1464.25 \\
\hline Linear & 2 & 1051.28 & 407.03 & 81.27 & 1055.28 & 1063.16 \\
\hline Quadratic & 3 & 972.96 & 78.32 & 2.95 & 978.96 & 990.79 \\
\hline Cubic & 4 & 970.01 & 2.95 & 0.00 & 978.01 & 993.78 \\
\hline General & 4 & 970.01 & - & - & 978.01 & 993.78 \\
\hline
\end{tabular}

